\title{
Cosmic Union of Communities: a New Concept and Technologies of Creating Cosmic Humanity
}

\author{
Sergey Krichevsky
}

\author{
Doctor of Philosophical Sciences, Professor, Institute of the History of Science and \\ Technology named after S.I. Vavilov RAS \\ (Moscow, Russia) \\ E-mail:svkrich@mail.ru \\ https://orcid.org/0000-0002-1094-7770
}

The article deals with the philosophical foundations of the theory and practice of creating Cosmic Humanity. It suggests a new idea, concept and technology of organizing cosmic communities, i.e. communities of people aspiring to space, striving to explore space, to fly and live beyond the Earth: the Cosmic Union of communities for the implementation of the superglobal project to create Cosmic Humanity. The methodological, social and technological aspects of the evolution of cosmic communities are described. The options, ways, models and projects of the institutionalization of such communities in the process of space exploration, as well as the creation of Cosmic Humanity are systematized. A brief analysis of the history and experience gained during the Space Age and the Space Revolution is made using the examples of the two types of Cosmic Humanity: (1) the global astronaut community (1959-2018) and (2) the Asgardian community - a megaproject of the first space state created in the cosmopolitan paradigm form of constitutional monarchy based on digital technology (2016-2018). A new powerful stream of people aspiring into space (more than 1 million people) has arisen and is growing. The problems and features of the transition process during the creation of Cosmic Humanity are shown. A general assessment of the potential and problems of applying new technologies is given. The features and risks associated with changes in the position and status of man in new cosmic communities and Cosmic Humanity, taking into account technical development and transformations in the process of space exploration, are highlighted. An "ultimate" hypothesis of the evolution of man, mankind and Cosmic Humanity was suggested. The main conclusions and recommendations are formulated.

Keywords: cosmic union, cosmic community, Asgardia, cosmic humanity, evolution, institutionalization, man, space exploration, space state, technology.

Received: October 10, 2018; accepted: October 28, 2018

Philosophy and Cosmology, Volume 22, 2019: 33-50.

https://doi.org/10.29202/phil-cosm/22/4

(C) Krichevsky, Sergey, 2019 


\section{Introduction}

Advancing in the analysis of philosophical foundations of the theory and practice of creating Cosmic Humanity [Krichevsky, 2017a $]^{1}$ in the evolutionary paradigm ${ }^{2}$, we will consider the aspects related to cosmic communities - communities of people aspiring to space, to explore space, to fly and live beyond the Earth ${ }^{3}$. The prehistory of cosmic communities derives from myths, literary works, science fiction, movies, etc., and then the birth of real scientific, engineering and other professional, formal and informal cosmic communities took place in the world. The history of the formation and institutionalization of the astronaut community is analyzed in the book [Ivanova \& Krichevsky, 2013]. Such cosmic communities of people are the natural basis of Cosmic Humanity.

The idea of creating Cosmic Humanity is reflected in the works and projects of a number of writers, philosophers, scientists, engineers, designers, entrepreneurs, among them: Jules Verne, Nikolai Fedorov, Konstantin Tsiolkovsky, Vladimir Vernadsky, Friedrich Zander, German Noordung (Potochnik), Sergey Korolev, Valentin Glushko, Ivan Efremov, Karl Sagan, Stanislav Lem, Leonid Leskov, Arkady Ursul, Stephen Hawking, Igor Ashurbeyli, Ilon Mask and others (see: [Cosmonautics of the $21^{\text {st }}$ century, 2010; Efremov, 1958; Krichevsky, 2017a; Lem, 1968; Leskov, 1996; Mirovaya pilotiruemaya kosmonavtika, 2005; Russkiy kosmizm, 1993; Sagan, 2005; Tsiolkovskiy, 1920, 1964, 1996, 2006; Ursul, 1995; Website "Asgardia — The Space Nation"; Website of SpaceX Corporation; Zander, 1988], etc.).

Konstantin Tsiolkovsky gave a detailed description of the process of creating Cosmic Humanity through the massive voluntary relocation of people from Earth to space in the unique futurological science-fiction story "Beyond the Earth" [Tsiolkovskiy, 1920], written in 1917-1918 during the catastrophic time of the social revolution in Russia.

In my view, Cosmic Humanity has long existed with the earthly humanity and gradually, more and more intensively grows out of it, realizing its cosmic mission. For more information about the stages of evolution and meta-goal setting — the rationale of Cosmic Humanity, see: [Krichevsky, 2017a: 53-54] and section 1.1 of this article.

The "cosmic revolution" began in the $20^{\text {th }}$ century and continues in the $21^{\text {st }}$ century: the transition from the earthly point of view to the cosmic point of view and to the new reality of man and mankind's existence, to physical outgoing beyond the Earth's boundaries through technology and technique, the transition to space exploration.

In the second half of the $20^{\text {th }}$ century, the idea of Cosmic Humanity began to be embodied in the practice of space activities, launches of space objects and human flights into space. In science and public consciousness, an extremely broad view of human spaceflight emerged

${ }^{1}$ There are published materials and research results of the author in 2016-2018 in S.I. Vavilov Institute for the History of Science the planned research on the history of space technology and activities and on the new theme: "Environmentally friendly aerospace projects and technologies of the $20^{\text {th }}-21^{\text {st }}$ centuries: history, trends, prospects” (state registration № 0002-2018-0003).

${ }^{2}$ On the evolutionary paradigm in the context of theory and practice, see: [Krichevsky, 2013, 2017a, 2018; Ursul \& Ursul, 2018; Yablokov et al., 2017]. In this article, the author continues to develop the ideas of managing evolution of the biosphere, technosphere, man and society.

${ }^{3}$ In this article, we will hereafter: 1) understand the communities of people of all forms of organization of society - from informal small communities to states, etc. 2) distinguish and designate the communities of people who aspire to fly into space, to live beyond the Earth precisely as "cosmic communities", given that in the broader view of cosmic communities, all the communities of people engaged in astronautics and space activities can be considered.

${ }^{4}$ See: “The Space Revolution” in Alexander Subetto's book [Subetto, 2015]. 
and exists as the beginning of the expansion of humanity beyond the Earth, with further resettlement in space. This was how the theoretical astronautics began and the practical one emerged "according to Tsiolkovsky" 100 years ago.

The space age, which started on October 4, 1957 with the launch of the first artificial Earth satellite in the USSR and then transferred to a new stage as a result of the first manned space flight on April 12,1961, is the "Space Revolution" that has changed the humanity and determines its future (after: [Subetto, 2015: 38-42]). That is, 60 years of the Space Age equals 60 years of the Space Revolution.

In the ultimate setting, the goal of the Space Revolution, space exploration is the creation of Cosmic Humanity [Krichevsky, 2017a, 2017b, 2018; Krichevsky \& Ivanova, 2018]. The possible ways (means, technologies) of achieving this goal are connected with the creation and development of new communities of people - cosmic communities.

There are two important examples of real and leading cosmic communities of people models and prototypes of Cosmic Humanity:

1. Global community of astronauts, including the national professional one, etc. (1959-2018) [Ivanova \& Krichevsky, 2013; Krichevsky \& Ivanova, 2018; Mirovaya pilotiruemaya kosmonavtika, 2005; Website "Kosmicheskaya enciklopediya ASTROnote"].

2. Community of participants of the global megaproject of the first space nation Asgardia (since 2016) [Igor Ashurbeyli, 2016; Krichevsky, 2017a: 60-65; Oleksenko \& Fedorova, 2017; Website "Asgardia — The Space Nation"].

There are dozens and even hundreds of examples of other cosmic communities (including national, planetary, lunar, martian and other societies, professional and public associations, united societies, etc.) related to the implementation of research and space exploration projects ${ }^{6}$. In the $21^{\text {st }}$ century, the number of such communities has increased, embracing all three sectors of modern society (state, commercial, non-profit): a lot of "space" nations of the world and non-governmental organizations - corporations as well as public organizations participate in the process of expansion of man and mankind into space. Millions of people on Earth take part in these growing cosmic communities?.

Moreover, cosmic communities have complex dynamics and features, cover various organizational forms (the whole range of possible forms and structures in the entire sociopolitical space is "anarchism - liberalism - etatism" (about this space, see: [Udartsev, 2016]) - from complete anarchy to the strict vertical state, corporate hierarchy), and the degree of "cosmicity" (from absolute focus on space activities to minimal participation in it). The creation and evolution of such cosmic communities proceed both under the influence of external and internal centralized control, and through self-organization. Moreover, these are the processes of self-organization, using the synergistic universal potential of anarchism and global network information systems, which have the greatest potential for creating and developing diverse cosmic communities, including space states, aspects of institutionalization, etc. ${ }^{8}$

${ }^{5}$ Alexander Subetto considers the beginning of the Space age to be the first human flight to space in 1961. This corresponds perfectly to the actual beginning of the physical expansion of a man beyond the boundaries of the Earth through the conventional boundary of the space, located above its surface at an altitude of $100 \mathrm{~km}$.

${ }^{6}$ These include the International Society of Philosophy and Cosmology (Kyiv), the author being its member.

${ }^{7}$ A general analysis of sociology and the dynamics of many cosmic communities is an important area of the research, but this is beyond the scope of this article.

${ }^{8}$ See: [Udartsev, 2012, 2016]. 
A new wave of space exploration by mankind, the spacization of individual and social consciousness, which covers millions of people on Earth, is rising, as well as the interest in new space projects and technologies, especially among young people, is growing (see: [Cosmonautics of the $21^{\text {st }}$ century, 2010; Krichevsky, 2017a, 2018]). This is largely facilitated by the introduction of new information technologies, informatization and digitalization of the society.

A new stage of space exploration and the prospects for creating communities of people beyond the Earth are discussed in modern scientific publications at representative international congresses and symposia, for example, in the report of Oleg Orlov and his co-authors: "Humanity is standing at the threshold of a new stage in space exploration - departure from Earth's orbit to explore the nearest objects in the Solar system, such as the Moon and Mars, with the prospect of building communities on these planetary bodies..." [Orlov et al., 2018].

At the same time, the process of space exploration is controversial, its rates turned out to be significantly lower than those projected at the beginning of the Space Age, and further until the end of the $20^{\text {th }}$ century and the beginning of the $21^{\text {st }}$ century [Galimov, 2010; Krichevsky, 2013, 2018]. The main problems are the following: 1) scarcity of resources allocated for space exploration, which is due to the proportions and limitations of terrestrial and space activities, including problems due to the aggravation of the global crisis on the Earth; 2) ineffective social and technical organization of space activities of the mankind; 3) lagging behind in the transition to fundamentally new space technologies.

The concept of space exploration, based on the paradigm of a divided and conflicting world community, since the beginning of the Space Age, has become obsolete and ineffective. For the upcoming new third period of the Space Age - the launch of the implementation of superglobal space exploration projects (see: [Krichevsky, 2018]) — it is necessary to develop a new concept for the organization of space activities.

There are complex problems, risks and limitations associated with the position and status of man in the process of space exploration, in new cosmic communities requiring the analysis, inventory and correction of structures and relationships in the created Cosmic Humanity.

To successfully implement the superglobal project for the creation of Cosmic Humanity, it is necessary to explore the problems of the theory and study the practical experience of the activities of cosmic communities, creation and introduction of new forms, ways of effective organization of society, provision of basic human rights in space exploration with the use of new social and technical technologies.

\section{Stages, meta-targeting, options, ways and projects of creating Cosmic Humanity}

\subsection{Steps and meta-targeting}

Cosmic humanity has long existed with terrestrial humanity and gradually emerges from it, with the coverage and expansion of the space of existence on Earth, in the near-Earth cosmic space, the near and far Space, with the emergence of new properties and relations in a complex superglobal system, "earthly humanity — cosmic humanity": "Cosmic humanity is (the essence and stages of evolution of human community - human civilization): 1 . Humanity, living on Earth, feeling, knowing, understanding its cosmic origin, the relationship with the Space and the cosmic purpose. 2. Humanity living on Earth conducting aerospace activities for the purpose of exploring and using aerospace (Heaven, Cosmos) for survival and development. 3. Humanity, living on Earth and beyond the Earth — in the Solar System, preserving the Earth and mastering Space for survival and development. 4. Humanity, settled 
and living in the Space. ... Now, humanity is in the process of transition from the $2^{\text {nd }}$ to the $3^{\text {rd }}$ stage. In the process of this evolution, a complex transformation of man and society takes place" [Krichevsky, 2017a: 53].

Meta-targeting is the justification of the purpose, necessity and possibility of Cosmic Humanity: 1. Survival and development of terrestrial humanity on Earth and in the space "Earth+" (Solar System + Galaxy + Universe). 2. The consequence of intelligent life evolution in the universe, that in accordance with the anthropic principle and its "active" super(post) anthropic complement, can be formulated in its outmost form as follows: "Cosmic Humanity has an evolutionary purpose to actively control evolution: to change a man, humanity and the Universe" (after: [Krichevsky, 2017a: 54]).

Thus, there are the processes of spacization and transformation of consciousness, existence and all activities of the earthly man and mankind, which are cosmic "by definition" and by their origin, since in the process of evolution they emerged and exist in the "Big" Space of the Universe, where the Earth is in the Solar system in our Milky Way Galaxy.

\subsection{Options}

Creation of the Cosmic Humanity can be considered in two basic options - "wide" (1) and "narrow" (2):

Option 1. Transformation of a unified earthly humanity, living only on Earth, into a single Cosmic Humanity living in the extending space of Earth + expansion.

Option 2. Creation of new Cosmic Humanity, independent of the earthly humanity ("Humanity-1") - "Humanity-2" (after: [Cosmonautics of the 21 $1^{\text {st }}$ century, 2010; Krichevsky, 1998; 2012]), "Neohumanity" (after: [Website of Strategic Public Movement "Russia 2045"], etc.

Option 1 does not exclude the subsequent separation from the single Cosmic Humanity, the autonomy and further development of new (separate) cosmic structures - communities, humanity, civilizations, etc. The transitional processes of creating a segment of a unified humanity beyond the Earth (for option 1) and the creation of Cosmic Humanity, autonomous from earthly mankind (for option 2), which is used by Asgardia, are of particular interest and complexity.

\subsection{Ways (methods, technologies)}

Possible ways (methods, technologies) of creating Cosmic Humanity through the nucleation and development of new cosmic communities:

1. Creation of units of professional astronauts, people's flights into space (including space tourists), permanent residence, life of groups, communities of people in space on artificial space objects, in artificial cosmic biosphere on spacecrafts, stations in near-Earth space, in bases, colonies, settlements on other celestial bodies - on the Moon, Mars, etc.

2. Unification of humanity on Earth, then the organization of massive cosmic expansion - resettlement beyond the Earth (after: [Tsiolkovskiy, 1920]).

3. Creation of space states for the development of space, expansion from Earth to space (after: [Udartsev, 2012, 2016]].

4. Others, including the synthesis of items $1-3$, and also - with fantastic viewpoint the possible entry into the community of cosmic civilizations of the Great Ring, (after Ivan Efremov, 1957 [Efremov, 1958]), etc. 


\subsection{Projects}

There are many (dozens or even hundreds) of social and technical projects for the creation of institutes and technical infrastructure of Cosmic Humanity. Among them, we distinguish six projects ( 3 in the $20^{\text {th }}$ and 3 in $21^{\text {st }}$ centuries), in chronological order:

1. Resettlement of mankind from Earth to Cosmos for a permanent life beyond the Earth (Konstantin Tsiolkovsky, 1917-1918) [Tsiolkovskiy, 1920].

2. Orbital space stations, settlements, colonies (J. O’Neil, 1974) [Gatland et al., 1986: 248-251].

3. "Cosmic volunteers" project, resettlement of humanity beyond the Earth, creation of "Humanity-2" (Sergey Krichevsky, 1993-2017) [Cosmonautics of the $21^{\text {st }}$ century, 2010: 177-183; Krichevsky, 1998; Krichevsky 2012: 230-236; Krichevsky, 2017a].

4. "AVATAR" project for the creation of cybernetic immortal man and humanity ("Neohumanity”) (Dmitry Itskov, 2012-2013) [Website of Strategic Public Movement "Russia 2045"].

5. Massive expansion into space, colonization of Moon and Mars (Ilon Mask, 20162018) [Website of SpaceX Corporation].

6. Space Nation of Asgardia (Igor Ashurbeyli, 2016-2018) [Igor Ashurbeyli, 2016, 2018; Krichevsky, 2017a: 60-65; Website "Asgardia — The Space Nation"].

\section{Communities of people who aspire to space: a brief history (two examples of the leading cosmic communities)}

Let us consider two real cosmic communities of people who strive to fly into space and live beyond Earth: (1) a global astronaut community, including national ones, etc. (19592018) [Ivanova \& Krichevsky, 2013; Krichevsky \& Ivanova, 2018; Mirovaya pilotiruemaya cosmonautica, 2005; Website "Kosmicheskaya enciklopediya ASTROnote"] and (2) the community of participants in the megaproject of the first space state of Asgardia (since 2016) [Website "Asgardia — The Space Nation"; Krichevsky, 2017a: 60-65; Oleksenko \& Fedorova, 2017].

\subsection{Community of astronauts}

The astronaut community was the first active model and prototype of the Cosmic Humanity; it was the first among the communities to go beyond the Earth into outer space (the first flight by Yuri Gagarin, April 12, 1961, the first man to exit to outer space from an orbiting spacecraft - Alexei Leonov, March 18, 1965, both of them were from the USSR; the first man to step foot on the Moon - Neil Armstrong, July 20, 1969, USA) and for more than 60 years has continued its extremely important mission, calling humanity into space, giving an example of anxiety in the future, self-sacrifice, overcoming risks, acquiring a unique experience in the development of complex space technology, accomplishing space flight, long life of a person beyond the Earth [Mirovaya pilotiruemaya kosmonavtika, 2005; Website "Kosmicheskaya enciklopediya ASTROnote"].

\section{The history of creating astronaut communities (first contests)}

In 1959, in the USSR, it was decided to select candidates from military fighter pilots for the first manned flight to space. 2 military pilots out of 3,456 contestants were selected. In 1960, the selected astronauts started a special program at the Air Force Cosmonauts Training Center of the USSR Ministry of Defense. At the same time, the decisions about the first manned 
flights into outer space were taken in the USA. NASA's announcement of the first enrollment of astronauts was responded by 508 test-pilots in 1959; 7 astronauts were selected and began training at Langley Research Center. The results of these contests: the first units of cosmonauts and astronauts, which became the basis of the professional astronaut community in the USSR and the USA, were created; the first flights of people to the near-Earth space were made in 1961.

\section{Astronaut contests — selection of people for space flights and society test for space maturity}

Since 1959 in the USSR / Russia, 37 enrollments have been conducted by several departments and organizations. A single corps of cosmonauts was formed by Roskosmos only in 2010. In total, 273 candidates were selected for astronauts, 121 of them ( 44\%) completed 258 space flights. ${ }^{9}$ In the USA 22 enrollments were conducted, 466 candidates were selected, of which 342 astronauts $(\sim 73 \%)$ performed 861 flights. In China, there were 2 enrollments of cosmonauts, 39 people were selected, of which $11(\sim 28 \%)$ completed 14 flights. In April 2018, the $3^{\text {rd }}$ enrollment was announced. In April 2018, besides the USSR / Russia, the United States and the People's Republic of China, candidates were selected in 41 countries of the world, 130 people from 36 countries were selected, of which 83 completed 124 flights (till April 12, 2018).

Unlike the closed ones, open contests give a more accurate idea of the "cosmic maturity" of people and society, have a powerful impact on the social consciousness, stimulate interest in space, they are a powerful advertisement and propagation of space activities. In the US, starting since the $2^{\text {nd }}$ (in 1962), almost all NASA contests have been open. In Russia, the first two open contests were in 2012 and 2017. In 2012 there were $\sim 300$ applicants $(\sim 2.1$ people per 1 million population of the country), in $2017 \sim 400(\sim 2.7$ people per 1 million). In the USA: in $2012 \sim 6800$ ( $\sim 20$ people per 1 million), in $2016 \sim 18,300$ ( $~ 56$ people per 1 million). In Canada: in $2016 \sim 4000(\sim 36$ million, $\sim 100$ people per 1 million $)$. In the United States, the EU, Canada, participation in open contests is prestigious. In 2015-2016, there was a special site for enrollment to NASA.

There are peculiarities of open contests in Russia: the procedure and requirements are bureaucratic, they limit the possibilities of citizens' participation, there is no site for registration, there is insufficient information about competitions in the mass media, and therefore in Russia there is no complete and reliable information about all those who wish to become cosmonauts. Probably, their number is 10 and more times higher than those who took part in the first open contests. However, the country has a rich experience in the training of cosmonauts, great opportunities and potential for effective public organization of nationwide contests for the selection of astronauts, including those for new superglobal projects for the development of the Moon, Mars, and others.

In total, the world community of cosmonauts (in 2018) enrolled about 1000 people (those who went through the selection and preparation for flights to space since 1959, of which about 220 people already died), about 600 people have been to space, including 8 space tourists. Now in the world, $\sim 100-150$ astronauts are active (preparing for flights, several people are in the near-Earth space on the International Space Station), for the whole period of the Space Age >

${ }^{9}$ The author pre-qualified for an astronaut; in 1989-1998, he was in a Cosmonaut corps of the Cosmonaut Training Center by Yu. Gagarin (USSR, Russia), a professional cosmonaut qualified as a test-cosmonaut (1991), was preparing as a crew commander for a flight on a transport spacecraft "Soyuz-TM" and for a long flight in the orbital manned "MIR" complex, but the space flight failed (see: [Mirovaya pilotiruemaya kosmonavtika, 2005; Website "Kosmicheskaya enciklopediya ASTROnote"]). 
100 thousand people in the world (possibly up to 300 thousand after the author's assessment) participated in all contests for the selection of astronauts.

The International Association of Participants in Space Flight was established and has been active (since 1985), it has national associations (in 2018 it had more than 400 people and 4 national associations), it unites into the special cosmic community only those who have orbited the Earth, and have the status of an orbiting astronaut, i.e. it is a narrower and more elitist community within the astronaut one.

In the coming years, a significant increase in the number of participants in space flights may occur in the event of mass flights of space tourists. ${ }^{10}$

At the same time, the astronaut community has a series of problems, risks, contradictions associated with high professional requirements, the specifics of the activities of astronauts, the properties of space technology, as well as the complex social relations in the selection and training of astronauts, because of the fierce competition for spaceflights, a significant social stratification due to differences in the status of astronauts (orbiting the Earth and non-orbiting), which is accompanied by conflicts within the astronaut community and with external systems under the influence of objective and subjective factors.

The community of astronauts has enormous professional, social experience and authority, has a significant influence on the formation of public opinion, the processes of spacization of the earthly humanity and implementation of the idea of Cosmic Humanity creation (see: [Ivanova \& Krichevsky, 2013; Krichevsky, 2017a, 2017b; Krichevsky \& Ivanova, 2018; Mirovaya pilotiruemaya kosmonavtika, 2005; Website "Kosmicheskaya enciklopediya ASTROnote"; Website "Yu. A. Gagarin Research \& Test Cosmonaut Training Center"]).

\subsection{Community of participants in the megaproject of the first space state of ASGARDIA}

In 2016-2018, a new more powerful stream of people aspiring to space arose. On October 12, 2016, Igor Ashurbeyli proclaimed and briefly outlined the idea and project of the creation of the cosmic nation and the $1^{\text {st }}$ space state of Asgardia. The concept of a megaproject consists of 3 parts: 1) philosophical; 2) legal; 3) scientific and technical. The total number of people striving to become Asgardia citizens was about 600 thousand on November 1, 2016. All these people stated their wish and entered the new cosmic community of Asgardia (see: Igor Ashurbeyli, 2016; Krichevsky, 2017a: 60-65; Asgardia — The Space Nation website). A draft Constitution was developed and published. On June 18, 2017, the Referendum on the Constitution of the Space Kingdom of Asgardia successfully took place. It was adopted and came into force. ${ }^{11}$

${ }^{10}$ At the same time, the fee for flying into space and, in fact, for purchasing the astronaut's status for a space tourist is extremely high and amounts to 200 thousand US dollars (for short flights) and up to several dozens of millions of dollars, generating social, economic and ethical problems when compared with living conditions and the capabilities of the overwhelming majority of the Earth's people, including hundreds of professional astronauts, who after a complex qualification for astronauts are preparing and waiting for flights to space for many years but most of them still do not perform these flights.

${ }^{11}$ Moreover, the choice of the system of governance (constitutional monarchy) and its name as well as the draft Constitution were made by the initiator and head of the Megaproject Asgardia Igor Ashurbayli in 2017, while according to the polls, most of the members of the Asgardia community at that time supported the parliamentary or presidential republic. As a result, in June 2017, only about $\sim 15 \%$ of all Asgardia members voted for this Constitution, the voting process went sluggishly and stretched out. The author, like many other members of the Asgardia community, participated in the discussion of the project, proposed amendments and was in great doubt in deciding on the voting due to the system of governance and the Constitution contents peculiarities. See: Constitution of Asgardia - The Space Kingdom. Website "Asgardia — The Space Nation". https://asgardia.space/assets/doc/constitution/ english.pdf 
On October 12, 2017, on the $1^{\text {st }}$ anniversary of Asgardia, the number of its citizens was officially about 103,000 people. On December 7, 2017, the first satellite (CubeSat) "Asgardia -1 " was put into the near-Earth orbit $\mathrm{H} \sim 500 \mathrm{~km}$ and activated (the launch was carried out by the USA). There is a database of the citizens of Asgardian and 18,000 personal files on its board. The satellite "Asgardia-1" is a national territory.

As of December 12, 2017, the Asgardian population accounted for about150 thousand citizens. In terms of the number (thousand people), the representatives of the following countries were in the lead: 1 . USA $\sim 21.0$ ( $\sim 40$ people per 1 million population); 2 . Turkey $~$ $18.0(\sim 200$ (!) per 1 million); 3. PRC $\sim 11.0(\sim 10$ per 1 million $) ; \ldots 10$. RF $\sim 4.0(\sim 18$ per 1 million). The human space potential of Turkey is very high, higher than that of the USA and China, although Turkey is not a leading space state and has not had astronauts yet. For Russia, the activity in Asgardia is 7 times higher than in the 2017 astronaut contests, i.e. it has large reserves at its disposal (!) [Krichevsky, 2017b]. On April 26, 2018, there were approximately 187 thousand citizens in Asgardia (after: [Website "Asgardia — The Space Nation"]).

The governmental bodies have been under the formation process. In 2018, the first elections to the Parliament (150 seats) took place in 13 constituencies (12 by language groups and 1 additional was formed during the elections to the Parliament), 124 deputies ${ }^{12}$ were elected and approved, including 6 deputies in District No. 7 (Russia), where there were 36 candidates $^{13}$ for approximately 6 thousand voters. On June 24, 2018, the first in-person meeting of the Parliament was held in Vienna, Austria, and the first laws were passed. The inauguration of the Head of State Igor Ashurbeyli was held on June 25 in Vienna, where he delivered an important keynote speech [Ashurbeyli, 2018; Website "Asgardia — The Space Nation"]. In August-September 2018, in accordance with Decree No. 20 of the Head of State, the first elections of mayors of Asgardian cities ${ }^{14}$ were held; they were elected in 44 cities of the digital state of Asgardia. On October 10-12, 2018, the $2^{\text {nd }}$ session of the Parliament was held, which was carried out for the first time in the distant, online digital format. On October 26-28, 2018, the first Asgardia Economic Forum was held in Nice, France. The first Government is in the process of formation. It is planned to apply to other states with proposals to recognize the state of Asgardia, and then apply for recognition in the UN [Website "Asgardia — The Space Nation"].

In the $1^{\text {st }}$ open and successful world space competition for the selection and creation of a new global cosmic community being the real prototype and the current model of space humanity in 2016-2018, there have already been over 1 million participants (about 1029 thousand), among them about 278 thousand people are residents of the new nation (as of

${ }^{12}$ See Decree No 21. On Affirmation of The Act on The First Parliament of Asgardia. August 07, 2018 [Website "Asgardia — The Space Nation"].

13 The author has been a member of the Asgardian community project since October 2016, he adopted the Constitution in June 2017, put forward his candidacy for participation in the elections to the Parliament in November 2017, presented and published the election Platform, the motto of which was "Save the Earth and create Cosmic Humanity"; in 2018, he was elected and approved as a Parliament deputy in Electoral District No. 7 (Russian); he is a member of the Committee on Science, actively participated in the first and second Parliament sessions.

${ }^{14}$ At the same time, a complex legal conflict arose, since the Asgardia Constitution does not contain divisions and provisions on local self-government, city mayors and their elections, which may lead to conflicts with some earthly nations, on whose territories there are real cities. Attempts to resolve this conflict by digitally interpreting the status of these cities and adopting new legal acts without amending the Constitution are unlikely to solve the problem. 
November 10, 2018). In terms of the number (thousand people), the representatives of the following countries were in the lead: 1 . Turkey $\sim 40.5 ; 2$. United States $\sim 33.1 ; 3$. India $\sim$ 20.8; 4. China $\sim 16.1 ; 5$. Russia $\sim 13.7$.

The most active are residents of five cities of the world: two cities in Turkey and one in Russia and China respectively: Istanbul (12883), Ankara (4449), Moscow (3585), and Beijing (2965). The map on the site displays the distribution and locations of citizens in the new space nation.

However, there are complex internal and external problems, the risks associated with the implementation of this megaproject. The real process of institutionalization, i.e. the transformation of the virtual community Asgardia, created since October 2016 on the information base of the non-governmental non-profit organization NGO "Asgardia" ("International Non-Governmental Research Society on Space - Asgardia"), based in the city of Vienna, Austria ${ }^{15}$, into the digital state Asgardia in a cosmopolitan paradigm, in the form of a constitutional monarchy within 2017-2018, was accompanied by the manifestation and growth of complex internal and external legal, organizational, communication, political, social, socio-cultural, economic, ethical and other problems and contradictions. This was most acutely manifested in the organization and conduct of the first elections and two Parliament sessions: candidates for deputies before the elections and elected deputies signed a non-disclosure agreement before their approval. As of November 10, 2018: the elected Parliament deputies cannot disclose any information about what happened at meetings of 2 Parliament sessions, which were held behind closed doors, public information about the work of Parliament is minimal, strict monopolistic control over the dissemination of this information and for all the activities of the Parliament is carried out by the Head of the State through his Administration (which is still at the same time the Administration of NGO "Asgardia"). Important legal acts are both not introduced and not adopted, though their necessity is established by the Constitution, and without them, the latter cannot act in full. Extremely difficult situation exists around the creation from scratch and the deployment of the Asgardia economy. All this is due to the properties and features of the selected model of the state and the Constitution, the real community of people, its leaders and the emerging elite, limited resources, a complex of objective and subjective factors of the transition period, and other aspects (see: [Harby, 2018; Website "Asgardia — The Space Nation"]).

At this stage, Asgardia needs to move from the euphoria of first successes and celebrations to overcoming the growing crisis through an organized, intensive process of nation-building in accordance with the Constitution, to actively and quickly creating the necessary legal framework and institutions, to institutionalizing all spheres of activity.

There are three possible scenarios for the development of this megaproject: 1) successful development, achievement of goals, creation of a space nation; 2) "hang" and stagnation; 3 ) termination and liquidation for internal and external reasons or when they are combined.

The idea and project of Asgardia are criticized, especially in organizations of the space industry, other cosmic communities and in the media as a utopia that has no prospects and is doomed to failure for legal, socio-political, socio-cultural, economic and technological reasons. And this criticism is justified. However, according to the author, this global social megaproject of creating a fundamentally new nation as an example of the institutional basis of Cosmic Humanity has the right to exist and the chances to be realized under the optimistic scenario (1), the favourable development of the overall situation on Earth,

${ }^{15}$ See: [NGO "Asgardia”. Website "Asgardia — The Space Nation". https://asgardia.space/en/ page/ngo--asgardia-] 
as well as within Asgardia, with the support and recognition by other states and the UN [Krichevsky, 2017a: 65].

\section{Cosmic Union of people, communities, states, civilizations of the Earth to create Cosmic Humanity}

\subsection{The idea and basis of a new concept}

The experience and the results of the exploration and use of space in the $20^{\text {th }}$ and $21^{\text {st }}$ centuries show that the existing concept of organizing space activities is ineffective and outdated. This concept is based on a system of individual measures and restrictions of the separated world community that were relevant for the first and second periods of the Space Age (the beginning and development of the space industry) [Krichevsky, 2018], where national and corporate interests, fierce competition (political, military, economic) prevailed and are still prevailing, while there is no single strategy, but there is a large deficit in the common goals of mankind, the institutions and mechanisms for their formation, coordination and achievement, including the pooling of efforts and resources.

Attempts to reorganize national and international space activities in the $21^{\text {st }}$ century on the base of market mechanisms of competition, revitalization of state organizations and especially private corporations, and commercial non-governmental organizations of public and private partnership are necessary but not sufficient.

The creation of new independent and self-sufficient cosmic communities, similar to the model of the space state [Udartsev, 2012], does not solve the problem; its example is a new community of the first space nation, as it is an independent sovereign digital space state Asgardia, that has been created as a constitutional monarchy by Igor Ashurbeyli since 2016, who has been the Head of the State since 2017 [Igor Ashurbeyli, 2016; Krichevsky, 2017a: 60-65; Website "Asgardia — The Space Nation"].

Together with important ideas, goals, first successes and achievements in 2017-2018, Asgardia experienced a growing and exacerbating complex set of problems and contradictions of the transition period (see section 2.2 of this text). There are chances and opportunities to successfully overcome this development crisis, but external and internal risks and difficulties are extremely great. Even in case of successful development of this global megaproject, due to the chosen model of the state, external competition and other factors, it is unlikely that Asgardia will be able to unite the whole mankind or its significant part in an attempt to create a unified space nation of humanity. But Asgardia gives the world an important example and experience, creates a powerful impetus for the start of a new global process of uniting mankind that is worthy of research and use in science, education and practice, for developing new strategies, creating new national and international institutions for the development of human society on Earth and in space.

For a new third period of the Space Age starting in the 2020s, when the implementation of superglobal space exploration projects begins, including the integrating superglobal project "Cosmic Humanity" (for more details on the periodization of the Space Age and the author's forecast for the third period, see: [Krichevsky, 2018]), the world community needs a new concept of the organization of space activities and space exploration.

The idea of a new concept: creation of a worldwide Cosmic Union of people, communities, states, civilizations of the Earth for the effective space exploration in order to survive and develop humanity on Earth and in Space, the implementation of the superglobal project "Cosmic Humanity". 
Such a union should unite all types, structures and forms of communities ${ }^{16}$ (and not only purely "cosmic" ones, but also those that approve and support space exploration and Cosmic Humanity creation) in the cosmopolitan paradigm on the principles of openness and voluntariness, it covers all three sectors of modern society.

As analogues of such a union, it is necessary to use the ideas and experience of international, interstate and other unions, including the UN, the EU, etc., as well as unions in various fields of society.

It is expedient and proposed in the near future to develop and adopt the "Universal Declaration of the Cosmic Union of Earth Communities for Space Exploration and Cosmic Humanity Creation" at the UN level, where a common strategy for space activities in the paradigm of united humanity was formulated for the first time. An analogue for the development of the draft Universal Declaration may be e.g. the Declaration and other documents created for the first space state Asgardia (2017-2018) [Website "Asgardia — The Space Nation"].

The foundations of the new concept should cover philosophical, legal, political, social, economic, technological, socio-cultural, environmental, ethical and other aspects of the Cosmic Union of Earth Communities. They can be presented in the form of a hierarchical system of higher goals, basic principles, priorities, trends, stages of organization and activities of the Cosmic Union.

\subsection{Problems and features of the transition process}

The creation of Cosmic Humanity, according to any of the possible options (see: section 1.2), will proceed in a complex transitional process, and this is clearly seen in the experiment on the example and experience of creation of the space nation Asgardia (see: section 2.2).

According to the definition of Sergei Udartsev, "a planetary federation or confederation of states seems to be an inevitable organizational form of human space civilization" [Udartsev, 2016: 152]. Sharing his opinion and the idea of creating a space civilization in an open "unifying", "synthetic" paradigm, it can be noted that the Asgardian state model is based on another closed "isolation" paradigm with a priority of independence and autonomy from other states; its potential is therefore limited.

At the same time, Asgardia has an open "window of opportunity" and a current active leader, the head of the space state, which enable to pass the transition period within the shortest possible time, and this is being implemented. There is an "ecological niche" for the existence and development of the nation, including the transition to a sustainable balanced nation when it reaches the "saturation stage". However, at the same time, there are significant difficulties in interacting with the outside world in order to gain recognition and carry out effective activities in the complex political and economic realities of the world community.

A more complicated, but also more natural and promising situation in the transition for option 1 through the proposed association - the Cosmic Union of Communities. ${ }^{17}$ However, the transition according to this option is significantly delayed and will take many years (possibly decades), since time is needed for agreement and adoption of the Declaration by participants within the process under conditions of separated humanity and the global crisis on Earth. Under the optimistic scenario, the unification can begin within the next 5 years and become significant and influential for the world community in about 40 years, i.e. to the $100^{\text {th }}$ anniversary of the Space Age in 2057.

\footnotetext{
${ }^{16}$ The main keyword here is "community", covering all structures: informal communities, states, etc.

${ }^{17}$ The space nation of Asgardia will also be able to enter the Cosmic Union, but the entry of other cosmic communities into the unitary state of Asgardia is impossible.
} 
However, to start the process, it is necessary that the idea of the Cosmic Union of Communities become widely known, enter the information, scientific and political space, receive support and begin to be put into practice.

This can be favored by the implementation of the megaproject Asgardia, which attracts considerable attention and is already well known in the world. Its successes and problems are already stimulating general interest in the idea of creating Cosmic Humanity, including through the creation of other cosmic states, in other forms as alternatives to Asgardia, as well as through the preliminary natural unification of humanity on Earth.

\section{Implementation technologies of superglobal project "Cosmic Humanity"}

For the implementation of the superglobal project "Cosmic Humanity", many new environmentally friendly and economical space technologies as well as the transition to a new technological order are needed. In the $20^{\text {th }}$ and $21^{\text {st }}$ centuries, a large number of aerospace inventions, patents, projects, start-ups, including eco-friendly ones, were developed and proposed, many of which are applicable and necessary for the business, but their implementation is hampered due to lack of support, funding and incentives. It is necessary to implement special megaproject initiatives to promote new environmentally friendly technologies (similar to the Clean Space Initiative in the ESA since 2013); and fundamentally new (yet not existing) technologies are to be created [Clean Space; Cosmonautics of the $21^{\text {st }}$ century, 2010; Gatland et al., 1986; Krichevsky, 2012, 2017a, 2018].

The superglobal project "Cosmic Humanity" can be realized only on the basis of a complex of new technologies: information, energy, transport, extraterrestrial natural resource extraction, medical, life support, protection of a man and the environment, etc., covering all spheres of human activity and society in space "Earth +" (the Moon, Mars, Solar System).

The mankind has created many of these technologies in the course of earthly and space activities, but stands at the beginning of the expansion process beyond Earth, of space exploration.

The need for practice of implementing the Cosmic Humanity project initiate a social order, stimulate and significantly accelerate creation and introduction of new technologies, as can be seen on the example of the Asgardia project.

Igor Ashurbeyli as the Head of the new State outlined the goals and frontiers of Asgardia for the next 25 years; they are ambitious and inspiring, but utopian and difficult to implement: 1) in 25 years, there will be 150 million people in the space state; 2 ) within the next $3-5$ years, space infrastructure will be created in near-Earth space from a network of small satellites for communication of Asgardian citizens, etc.; 3) in 10-15 years, "space arks" will appear in near-Earth space, these are settlements for the permanent life of people in near-Earth space, where there will be: (a) protection from radiation, (b) artificial gravity and (c) solved problem of human reproduction in space; 4) in 25 years, the constant base on the Moon (after: [Ashurbeily, 2018; Website "Asgardia — The Space Nation"]).

This will require development and implementation of fundamentally new technologies for the creation and functioning of Asgardia infrastructure in space in an extremely short time. However, due to technical and economic reasons, it is unlikely that these plans will be implemented within the specified time limits for paragraphs 3) and 4), especially in paragraph 3 ) (c) as the risks associated with human reproduction in space are extremely high. ${ }^{18}$

${ }^{18}$ See: [Krichevsky, 2012; 2017a: 59-60, 2018; Morozov, 2018]. 
All this can happen if there is a powerful scientific and technical breakthrough and a new technological revolution in the field of space technology, which will lead to a greening of space technology and activity.

\section{Man in Cosmic Communities and in Cosmic Humanity}

The position and status of a person in cosmic communities depend on the goals, forms, and characteristics of specific communities, social relations and the man's role in them.

Participation in the projects of creating Cosmic Humanity expands the possibilities and increases the chances of people to fulfill the cosmic dream of flying and living in space. At the same time, a person is forced to observe both the changing "rules of the game" of the cosmic community, of Cosmic Humanity, and existing features in comparison with ordinary earthly ones.

Human interaction with the new technology, including artificial intelligence systems, robotics, creates fundamentally new opportunities for space exploration, life support and human safety outside the Earth, but also generates new risks for humans, communities and the whole mankind.

For example, training and human activity in the professional communities of astronauts is becoming increasingly complex, automated, computerized, virtualized and robotized.

Anthropomorphic astronaut assistant robots have been created and are being tested, astronauts are being trained on their use; and they will be used in future in space flights on the International Space Station, etc. ${ }^{19}$ In the future, astronaut training centers may turn into programming and adaptation centers for anthropomorphic robots-astronauts (as models and prototypes of cybernetic astronauts, cyborgs, "quasi-human", "post-human", etc., — see: [Cosmonautics of the $21^{\text {st }}$ century, 2010; Krichevsky, 2012, 2013]) for space flights, research and space exploration, training of management and interaction skills.

There are serious dangers, risks, limitations for man and mankind in space, as well as critical views on achievements in space, development and prospects of man and society in this connection. At the beginning of the Space Age in the 1960s, Hannah Arendt in her philosophical essay "The Conquest of Space and the Stature of Man" made an important analysis of the destructive influence of space conquest on man and our future (after: [Arendt, 2014: 390-412]). Vladimir Kutyryev sharply criticizes human exploration of space, transhumanism, man's transformation, "trans-human" and post-human (see: [Kutyryev, 2015]). There is a real threat of "dehumanization", as well as the degeneration and death of man and mankind in space, including those due to the problems of human reproduction in space, due to the impact of negative environmental factors outside the Earth.

New technologies, projects and transformations can radically affect the future of man and mankind; therefore, they require advanced analysis, examination, solution of the most complex set of problems (ethical, legal, medical, social, technical, environmental, etc.), introduction of a number of restrictions and even a moratorium on implementation of a number of projects and technologies (after: [Krichevsky, 2017a: 59-60]).

All these aspects are necessary and are to be researched and taken into account, including in the context of fundamental human rights and their changes, when creating new cosmic communities, Cosmic Humanity, the expansion of man and society beyond Earth. It is possible that the humanity will have to stop at a certain border and thoroughly prepare, wait or create a new wave for further successful entering the space. Apparently, this will lead to the formation of new cosmic communities.

\footnotetext{
${ }^{19}$ See: [Website "Yu. A. Gagarin Research \& Test Cosmonaut Training Center"].
} 
And, finally, the "ultimate" hypothesis of the evolution of man, mankind, Cosmic Humanity: in the absolute limit (beyond the limits of the present and possible from the modern perspective) "astronaut quasi-human" (after Yuri Baturin and Oleg Dobrochev, 2010), "cosmic universal human" (after Sergey Krichevsky, 2010, 2012): [Cosmonautics of the 21 $1^{\text {st }}$ century, 2010: 180-183, 694-697; Krichevsky, 2012]), "cybernetic immortal human" (after Dmitry Itskov, 2012) [Website of Strategic Public Movement "Russia 2045"], "radiant human" in "radiant humanity" (after Konstantin Tsiolkovsky, the 1930s) [Tsiolkovskiy, 1986], "post-posthuman, living universal rational being" (after Sergey Krichevsky: [Krichevsky, 2013]) can become autonomous and independent from cosmic communities and Humanity. This will lead to the disintegration of human communities, earthly and Cosmic Humanity, their complete elimination (disappearance) or gradual transformation into other structures ("cloud", "radiant", etc.). Then the mission of man, mankind and Cosmic Humanity will be completed, the mission is entirely fulfilled or, under their "ultimate" and final impact, including due to the contact with another (extraterrestrial) civilization, the possible entry into the union of cosmic civilizations of the Great Ring (after Ivan Efremov, 1957 [Efremov, 1958]), etc. the transformation of man, mankind, Cosmic Humanity, Earth, Solar System, Galaxy, Universe may occur and a new cycle will begin with the creation and subsequent evolution of the universal supernew super-live supramental (?).

\section{Conclusion. Key findings and recommendations}

1. Theoretical and practical issues of creating Cosmic Humanity based on cosmic communities of people seeking to explore space, fly and live beyond the Earth, including examples of two real and leading communities: the astronaut community and the megaproject Asgardia were analyzed.

2. In 2016, there appeared a new powerful stream of people aspiring into space (more than 1 million people): the Asgardia megaproject for the creation of the first space state is being implemented, i.e. a new global cosmic community of people, an actor and leader of the process of creating Cosmic Humanity. The analysis of a number of events, results and problems of this important social megaproject and experiment was conducted.

3. It is advisable to continue research of cosmic communities to obtain correct data in dynamics, comparative analysis of information, together with taking into account the data on the Asgardia megaproject.

4. The world community needs a new concept and strategy for organizing space activities in the new third period of the Space Age starting in the 2020s, i.e. with the beginning of the implementation of superglobal space exploration projects, including the integrating project "Cosmic Humanity".

5. The idea and the basis of a new concept as well as implementation technology of the super-global project to create Cosmic Humanity were presented.

6. It was proposed to transit from ineffective international cooperation in the exploration and use of space based on the outdated concept in the paradigm of the separated world community to the creation of a world Cosmic Union under a new concept within the paradigm of united humanity, to develop and adopt the "Universal Declaration of the Cosmic Union of Earth Communities for Space Exploration and Cosmic Humanity Creation" at the UN level. 
7. The analysis of technologies necessary for the implementation of the superglobal project of Cosmic Humanity was carried out; the aspect of fundamentally new environmentally friendly technologies was highlighted.

8. The opportunities and risks associated with a change in the position and status of man in the process of space exploration in new cosmic communities and Cosmic Humanity were revealed, taking into account technical development; a "ultimate" hypothesis of the evolution of man, mankind and Cosmic Humanity was suggested.

9. It is advisable to continue researching the best structures, forms, models and technologies for organizing new cosmic communities, space states with the aim to create Cosmic Humanity.

\section{References}

Arendt, Hannah. Mezhdu proshlym i buduschim. Moskva: Izdatelstvo Instituta Gaydara, 2014. (In Russian).

Ashurbeyli, Igor. Inauguration Speech. 25 June 2018. https://www.ashurbeyli.ru/chronicle/ article/inauguration-speech-17290

Clean Space / Green technologies. Website of ESA. http://www.esa.int/Our_Activities/ Space_Engineering/Clean_Space/Green_technologies

Cosmonautics of the $21^{\text {st }}$ century: Attempt of the Forecast of Development till 2101. Ed. by Boris Chertok. Moscow: RTSoft, 2010. (In Russian).

Efremov, Ivan. Tumannost' Andromedy. Moskva: Molodaya Gvardiya, 1958. (In Russian).

Galimov, Eric. Concepts and Failures: Fundamental Space Environment Research in Russia of the Last Twenty Years. Twenty Years of Unsuccessful Efforts. Moscow: Editorial URSS, 2010. (In Russian).

Gatland, Kenneth, Mitchell Sharp, David Skinner and others. Space Technology: Illustrated Encyclopedia. Moscow: Mir, 1986. (In Russian).

Igor Ashurbeyli ob'yavil o sozdanii pervogo $v$ istorii kosmicheskogo gosudarstva. 15 oktyabrya 2016. http://www.ashurbeyli.ru/chronicle/article/igor-ashurbeyli-obyavilo-sozdanii-pervogo-v-istor-16356 (In Russian).

Ivanova, Lidiya, and Sergey Krichevskiy. Soobshchestvo kosmonavtov. Istoriya stanovleniya i razvitiya za polveka. Problemy i. Perspektivy. Predisl. Viktora Savinyih. Moskva: LIBROKOM, 2013. (In Russian).

Harby, Bill. Asgardia: The problems in building a space society. BBC - Future. 3 August 2018. http://www.bbc.com/future/story/20180803-asgardia-the-problems-inbuilding-a-space-society

Krichevsky, Sergey. Aerospace Activities: Interdisciplinary Analysis. Moscow: LIBROKOM, 2012. (In Russian).

Krichevsky, Sergey. Kosmicheskoe budushchee cheloveka i chelovechestva: problemy i perspektivy [The Cosmic Future of Man and Mankind: Problems and Prospects]. Filosofskie nauki [Russian Journal of Philosophical Sciences]. 9, 2013: 38-43. (In Russian).

Krichevsky, Sergey. Cosmic Humanity: Utopia, Realities, Prospects. Future Human Image. 7, 2017a: 50-70. (In Russian).

Krichevsky, Sergey. Cosmonautics and Civilian Society. Space Governance. The Journal of United Societies in Space and The World-Space Bar Association. 5 January 1998: 34-39. 
Krichevsky, Sergey. Pochemu v Rossii razlyubili polety v kosmos. Vozdushno-kosmicheskaya sfera. 2017b. № 4: 18-25 (In Russian).

Krichevsky, Sergey. Super Global Projects and Environmentally Friendly Technologies Used in Space Exploration: Realities and Prospects of the Space Age. Philosophy and Cosmology. 20, 2018 : 92-105.

Krichevsky, Sergey, and Lidiya Ivanova. Konkursy po otboru kosmonavtov i soobshchestvo lyudej, stremyashchihsya $\mathrm{v}$ kosmos: istoriya i perspektivy. Institut istorii estestvoznaniya i tekhniki im. S. I. Vavilova. Godichnaya nauchnaya konferenciya, 2018. Moskva: Yanus-K, 2018: 309-312. (In Russian).

Kutyirev, Vladimir. Nebyitie tozhe opredelyaet soznanie. Nezavisimaya gazeta. Prilozhenie "NG-Nauka." 27.05.2015. http://www.ng.ru/nauka/2015-05-27/12_transgumanism. html (In Russian).

Lem, Stanislav. The Sum of Technology. Moscow: Mir, 1968. (In Russian).

Leskov, Leonid. Kosmicheskoe buduschee chelovechestva. Moskva: ITAR-TASS, 1996. (In Russian).

Mirovaya pilotiruemaya kosmonavtika (Istoriya. Tehnika. Lyudi). Pod red. Yuriya Baturina. Moskva: RTSoft, 2005. (In Russian).

Morozov, Sergey. Gomeostaticheskij kovcheg kak glavnoe sredstvo v strategii osvoeniya kosmosa. Vozdushno-kosmicheskaya sfera. 2018. № 3: 28-37. (In Russian).

Oleksenko, Roman and Lidiia Fedorova. Homo Economicus as the Basis of "Asgardia" Nation State in Space: Perspective of Educational Technologies. Future Human Image. 7, 2017: 113-119.

Orlov, Oleg, William Paloski, Peter Graef, Mark Belakovsky and Leticia Vega. International cooperation in solving the medical and biological issues of space explorations missions. Abstract. 69 $9^{\text {th }}$ International Astronautical Congress 2018. Paper ID: 43657. https://iafastro.directory/iac/paper/id/43657/abstract-pdf/IAC-18,A1,4,1,x43657. brief.pdf?2018-03-29.12:12:56

Russkiy kosmizm: Antologiya filosofskoy myisli. Sost. Svetlanyi Semenovoy i Anastasii Gachevoy. Moskva: Pedagogika-Press, 1993. (In Russian).

Sagan, Karl. Kosmos: Evolyutsiya Vselennoy, zhizni i tsivilizatsii. Sankt-Peterburg: Amfora. 2005. (In Russian).

Subetto, Alexandr. Revolyuciya i ehvolyuciya (metodologicheskij analiz problemy ih sootnosheniya). Pod nauchnoj redakciej L'va Zelenova. Sankt-Peterburg : Asterion, 2015. (In Russian).

Tsiolkovskiy, Konstantin. Vne Zemli. Kaluga: Izdanie Kaluzhskogo Obschestva Izucheniya Prirodyi i Mestnogo Kraya, 1920. (In Russian).

Tsiolkovskiy, Konstantin. Reaktivnyie letatelnyie apparatyi. Moskva: Nauka, 1964. (In Russian).

Tsiolkovskiy, Konstantin. Mirazhi budushchego obshchestvennogo ustrojstva: Sb. statej. Moskva: Samoobrazovanie, 2006. (In Russian).

Tsiolkovskiy, Konstantin. Grezy o Zemle i nebe: Nauchno-fantasticheskie proizvedeniya. Tula: Priokskoe knizhnoe izdatel'stvo, 1986. (In Russian).

Udartsev, Sergey. Ideya kosmicheskogo gosudarstva v istorii politicheskoy myisli. Pravo $i$ politika. 2012. № 8: 1386-1399. http://www.nbpublish.com/library_get_pdf. php?id=21007 (In Russian).

Udartsev, Sergey. Filosofiya prava anarhizma. Saarbrücken, Deutschland: Palmarium Academic Publishing, 2016. (In Russian). 
Ursul, Arkadiy. Kosmicheskie perspektivy avtotrofnosti chelovechestva. Obschestvennyie nauki i sovremennost. 1995. № 2: 131-139. (In Russian).

Ursul, Arkady, and Tatiana Ursul. Universal (Global) Evolutionism. Philosophy and Cosmology. 20, 2018: 33-41.

Yablokov, Alexey, Vladimir Levchenko and Anatoly Kerzhentsev. The Biosphere as a Living System. On the Harmonization of Human and Biosphere Relationship. Philosophy and Cosmology. 18, 2017 : 54-83. (In Russian).

Website "Asgardia — The Space Nation". https://asgardia.space/

Website "Kosmicheskaya enciklopediya ASTROnote". http://astronaut.ru/index.htm

Website of SpaceX Corporation (USA). http:/www.spacex.com/

Website of Strategic Public Movement "Russia 2045". http://www.2045.ru/

Website "Yu. A. Gagarin Research \& Test Cosmonaut Training Center". http://www.gctc.su/ Zander, Frederick. Problems of interplanetary flights. Moscow: Nauka, 1988. (In Russian). 